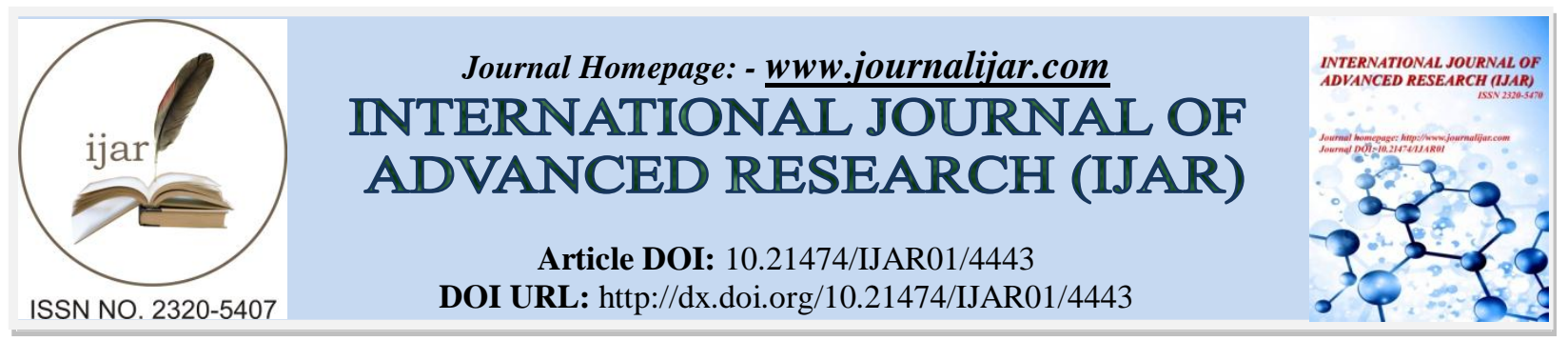

RESEARCH ARTICLE

\title{
PRIMARY EDUCATION AND SCHOOL TEACHERS; AN ANALYSIS OF POLICY INITIATIVES AND ITS CONTRADICTIONS: A CASE STUDY OF KAITHAL DISTRICT, HARYANA (INDIA).
}

Uma Sheokand.

Research Fellow, Panjab University, Chandigarh (India)-160014.

\section{Manuscript Info}

Manuscript History

Received: 11 April 2017

Final Accepted: 13 May 2017

Published: June 2017

Key words:-

Education for All, Teachers, Educational

Growth, Kaithal District

\section{Abstract}

An attempt has been made in paper to discuss the policy initiatives by Government of India. The central focus of the paper is to throw light on the success achieved, challenges faced and remedies to overcome challenges of universal primary education and to identify condition of primary teachers at the grass root levels with a case study of Kaithal district. India under the flag of international campaign of "Education for All" has taken several initiative programmes, policies and practices to reach educational goals in the nation. There has been great progress in the last decade in primary education in India. The gender, caste and demographic disparities in primary education have markedly reduced at national, state and at grass root levels. But challenges like problems of guest teachers, untrained or semi trained teachers, salaries and service conditions of private school teachers, precise policies for school teachers are still big hurdles in achievement of universal goals of primary education, which demands strong political will, reality based initiatives and administrative dedication of the educational authorities.

Copy Right, IJAR, 2017,. All rights reserved.

\section{Introduction:-}

The glory of Guru is that, without whose help; one cannot cross this ocean of worldly life. American Commission of Teacher Education "The quality of a nation depends upon the quality of its citizens. The quality of its citizens depends upon the quality of their education. The quality of their education depends upon the quality of their teachers"

The educational system is the foundation for the development of any country. Education is the soul of the nation and is the gateway to progress, prosperity and establishment of social justice in the nation. According to a report by NEUPA (2002) "Teachers are the main human resource for the educational development in country. Provision of infrastructural facilities in the schools however does not guarantee that children would learn." ${ }^{\text {Certainly teachers }}$ are the most essential raw material for the development of education system. They are the indispensable source to impart education to the students. Aristotle regarded the role of teachers more consequential than the parents. Teachers have responsibility of building the fate of the nation, because nation depends on the strength of education system. Education system cannot be expected to reach to its optimum value without undertaking the demands of teachers and due recognition to their academic, personal and professional needs of teachers are a matter of prime

\footnotetext{
${ }^{1}$ http://www.nuepa.org/libdoc/e-library/articles/2002nsood.pdf Accessed on 12, March 2014.
} 
concern. 'Teachers are unarguably the paramount group of professionals for the nation's future; therefore it is disquieting that many of today's teachers are not happy with in the profession.

\section{Objective:-}

The objective of the subject matter is to analyze the position of primary teachers at grass root level with a case study of Kaithal district while stating various national initiatives undertaken by Government of India to improve the primary education.

\section{Methodology:-}

For analyzing the results of international campaign of Education for All initiative and other national initiatives for upliftment of primary education in India, secondary data have been used. As the subject matter focuses on the analysis of the condition of Primary education in India the data have been collected from National Educational University of Planning and Administration (NEUPA), Department of Statistical and Economic Abstract Haryana, District Information System for Education (DISE) website for the analysis of the condition of Primary education in India and in Kaithal District in Haryana. Besides it, the analysis of newspaper reports and authentic online data will also form the part of data. This paper also enlisted the growth of Primary education in Kaithal district that has undergone in last decade on the basis of available data.

\section{National Perspective and Education for All Campaign:-}

India's commitment to the goal of Education for All is exemplified by range of strategies and actions initiated since 1990 to achieve the goal of 'Education for All' in the shortest possible time period. India has, laid down under the Article 45 that "The state shall endeavor to provide within a period of 10 years from the commencement of this Constitution for the free and compulsory education of all children until they complete the age of fourteen." Education in India has been on the 'Concurrent List' since 1976. There is meaningful partnership between the Centre and States. There are constitutional provisions and mechanisms for sharing of resources, planning, division of powers and responsibilities and harmonization of their respective powers in the larger national interest and welfare. Government of India has taken strong steps with a view to realizing the Constitutional Directives of Universal Elementary Education (UEE).

Key milestones in India's March towards Primary Education:-

The Indian government took several steps including the setting up of the education Commission besides framing many programmes and policy initiatives, which are as follows:

* Kothari Commission (1964-66)

* The National Policy of Education (NPE) 1968

* National Policy of Education (NPE) (1986 and 1992) ${ }^{2}$ Many initiatives were taken under the umbrella of this policy i.e.

* National Literacy Mission (1988)

* Minimum Levels of Learning (MLL)Programme (1991)

* Programme of Action (POA) (1992)

* National Advisory Committee (1992)

* District- specific programmes (1993)

* District Institute of education and Training (DIETs) were structured as per the needs of district and effectiveness of institutions.

* State Councils for Educational Research and Training (SCERTs) were strengthened for purpose of recruitment of appropriate faculty, linking of DIETs, resource centres, maintenance of school buildings etc.

* Programme of Sarva ShikshaAbhiyan (SSA) ${ }^{3}$ Sarve Shiksha Abhiyan (SSA) is a nation wide, time- frame programme, for quality and basic universal primary education in India with the effective partnership between Central, State and Local governments by involving the Panchyaty Raj institutions, the School Management Commettees, Village Education Commettees, Parents' Teachers Associations to reach its objectives. It aims to bridge the social and gender gaps with active participation of community in management of schools. It implemented institutional reforms as part of the SSA

\footnotetext{
${ }^{2}$ National Policy on Education, (NPE), (1886) Ministry of Education, Government of India, New Delh.

${ }^{3}$ Available at www.ssa.nic.in/, Accessed on 7, March 2013
} 


\section{* The Right of Children to Free and Compulsory Education Act (RTE), 2010}

The RTE Act provides legal entitlement to free and compulsory education to all children. This act mandated norms, standards, free entitlements, provided a justifiable legal framework that entitles all children between the ages of 6-14 years for free of cost and compulsory admission, attendance and completion of elementary education in India.

Realignment of programmes: Steps have been initiated to harmonize the vision, strategy and norms under Sarva Shiksha Abhiyan (SSA) with RTE norms which lead to their realignment with each other. ${ }^{4}$ Many steps by government for the improvement of the delivery system of elementary education under SSA are, Community ownership, Institutional Capacity Building by improving the role of major agencies i.e. NIEOA, NCERT, SCERT etc.

\section{Primary Education in Kaithal District: Major Findings and Remonstrance:-}

There is brief review of the progress made in with respect to each of the Education for All goals and the challenges that remain to be addressed at grass root level.

\section{District Kaithal, Haryana:-}

The District Kaithal was set up in 1989 by reorganizing the districts of Kurukshetra and Jind of Haryana state. ${ }^{5}$ Beside the high density and economically backward area, it has achieved many of the objectives of education after coming into existence as independent district.

\section{Enrolment in Primary Classes in Kaithal District:-}

The chart 1.1 showing that total enrolment in primary classes increased from 2010 to 2013. The enrolment in government primary schools was much higher in 2010-11 but by 2012-13 enrolments in government school decreased, while the enrolment in private schools increased in the same year; as it may be seen in chart 1.1.

Chart 1.1:- Total Enrolment in Government and Private Primary Schools in Kaithal District (2010 to 2013)

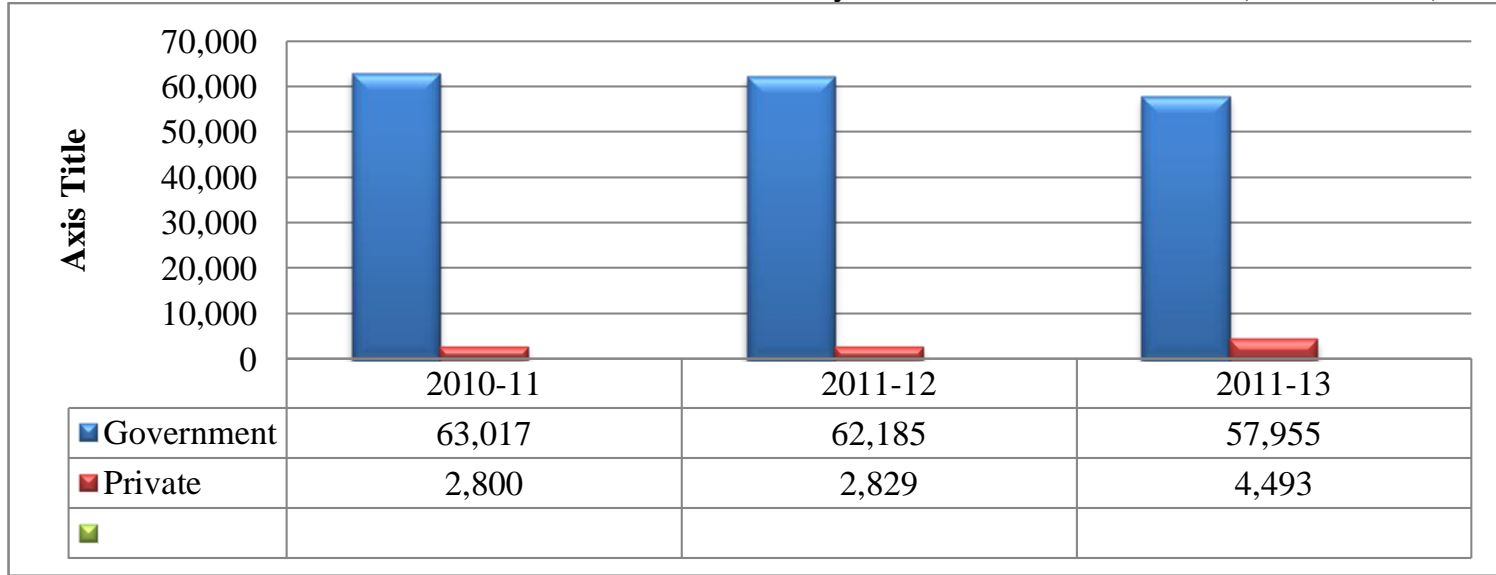

Source: DISE Report District: Kaithal, Year 2010-11; 2011-12 and 2012-13 Elementary Education in India- Where do we stand? District: Kaithal P. 184

Gross Enrolment Ratio and Net Enrolment Ratios:-

There was significant growth in Gross Enrolment Ratio (GER) and Net Enrolment Ratios (NER) from 2008-09 to year 2012-13; the GER and NER increased to $104.3 \%$ and $81.9 \%$ respectively in 2012-13 as is manifested in Chart 1.2 .

\footnotetext{
${ }^{4}$ Report to the People on Education, (2011-12), New Delhi; Ministry of Human Resource and Development (MHRD) Government of India, pp. 14- 31

${ }^{5}$ Available at, http://kaithal.nic.in/education.htm (2013) (Accessed on 1, Feb 2013)
} 
Chart 1.2:- Showing Gross enrolment and Net Enrolment Ratio in Kaithal District Haryana

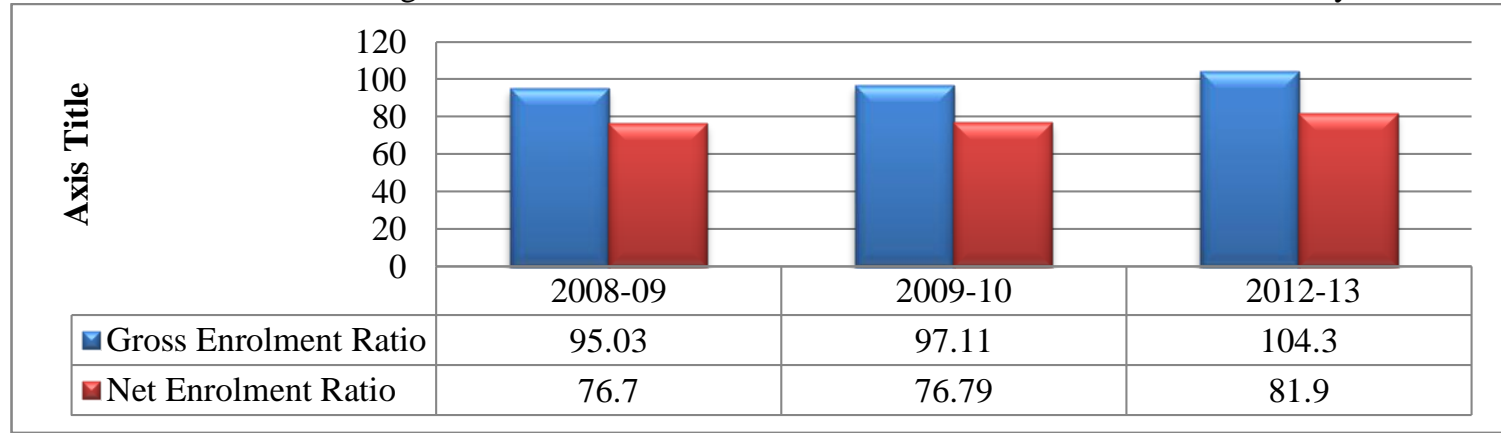

Source: DISE Report District: Kaithal, Year 2010-11; 2011-12 and 2012-13 Elementary Education in India- Where do we stand? District: Kaithal P. 18.

\section{Grade Wise Enrolments of Students in Kaithal District:-}

Dropout rate of students in primary classes is one of the hindrances in the achievement of EFA goals. Chart 1.3 showing the grade wise steady growth in enrolment in schools in Kaithal district. As the chart 1.3 also indicates that there was substantial growth in grades I and V in 2012-13. There was increase in the fifth grade student in the schools, which reveals the retention rate increased from 2010-11 to 2011-12. The chart 1.3 shows diverse trends in the enrolment ratio of the students in Kaithal district in Haryana.

Chart 1.3:- Grade Wise Enrolment in Primary Schools in Kaithal District from 2010 to 2013

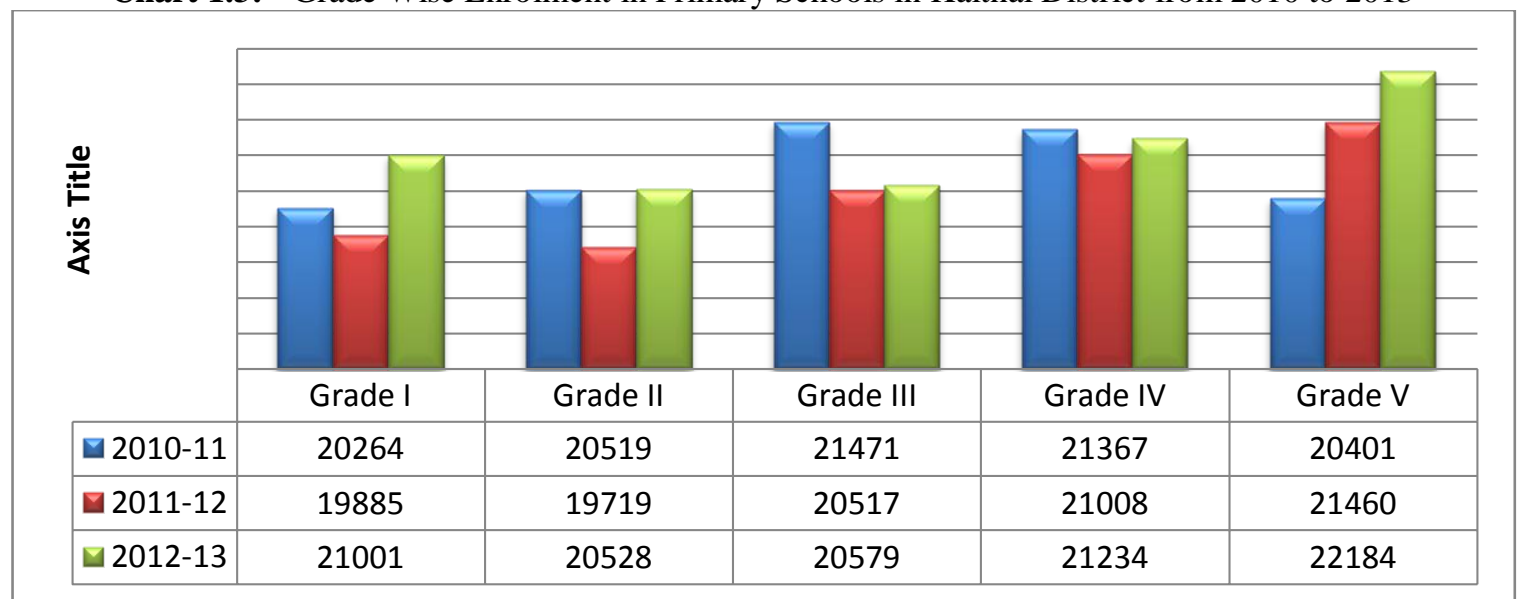

Source: DISE Report District: Kaithal, Year 2010-11; 2011-12 and 2012-13 Elementary Education in India- Where do we stand? District: Kaithal

\section{Teachers in Kaithal District:-}

If there is increase in the growth of child population in the nation, the need for more teachers also increases automatically. With the increase in child population there is increase in the growth of schools and other facilities in those schools as well as there are growth in teacher's related indicators.

Total strength of Primary school teachers in Kaithal district was 6562 in 2010-11 as is shown in Table 1.1. Male female teachers' ratio should be maintained for better education in primary education; as female teacher are better than male teacher when it comes to primary education. But the table 1.1 clearly depicts that the strength of female teachers was much less as compared to male teachers in Kaithal district. 
Table 1.1:- Number of Teachers in Primary Schools in Kaithal District (2010-11)

\begin{tabular}{|l|l|l|l|}
\hline Year & Male & Female & Total \\
\hline $\mathbf{2 0 1 0 - 1 1}$ & 3288 & 2100 & 6562 \\
\hline
\end{tabular}

Source :District Statistical Abstract, Department of Economic and Statistical Analysis Haryana

Single Classroom Schools and Single Teacher Schools:-

Government of centre and states has focused on infrastructure and availability of schools in Haryana. There has been significant reduction in number of single classroom and single teacher schools as may be seen in chart 1.4; which reveals that there is phenomenal growth in the school infrastructure as well as single teachers in schools from 2010 11 to 2012-13.From 2010 to 2013, the percentage of single classroom schools reduced from 4.8 to 2.6 and the percentage of single teachers schools too reduced from 6.5 to 5 percent as may be seen in table 1.4.

Chart 1.4:- Percentage Rate of Single Classroom Schools and Single Teacher Schools in Kaithal District from 2010 to 2013

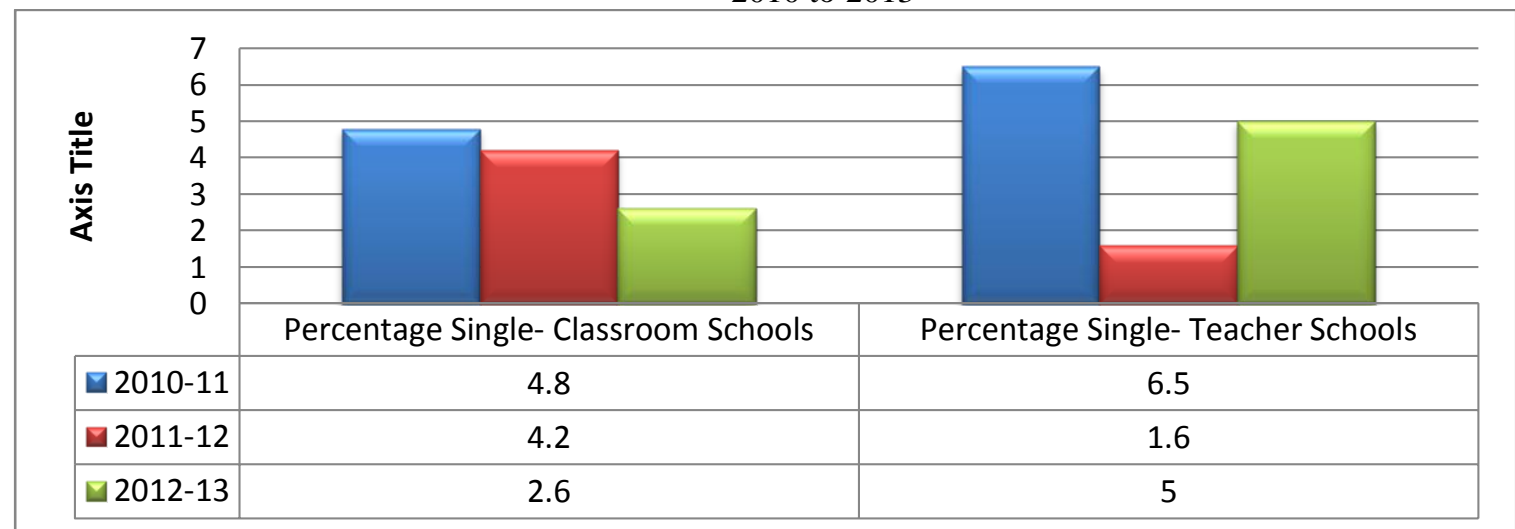

Source: DISE Report District: Kaithal, Year 2010-11; 2011-12 and 2012-13 Elementary Education in India- Where do we stand? District: Kaithal

\section{Schools with No Female Teachers:-}

Chart 1.5 indicates that there is decrease in the percentage of schools with no female teachers. There were $30.9 \%$ schools without female teacher in 2010 , which decreased to $30 \%$ in 2013 . In $2010-11$ there were $39.1 \%$ schools having at least one female teacher; this number reduced to $30 \%$ in 2012-13.

Chart 1.5:- Percentage of Schools with No Female Teachers in Kaithal District from 2010 to 2013

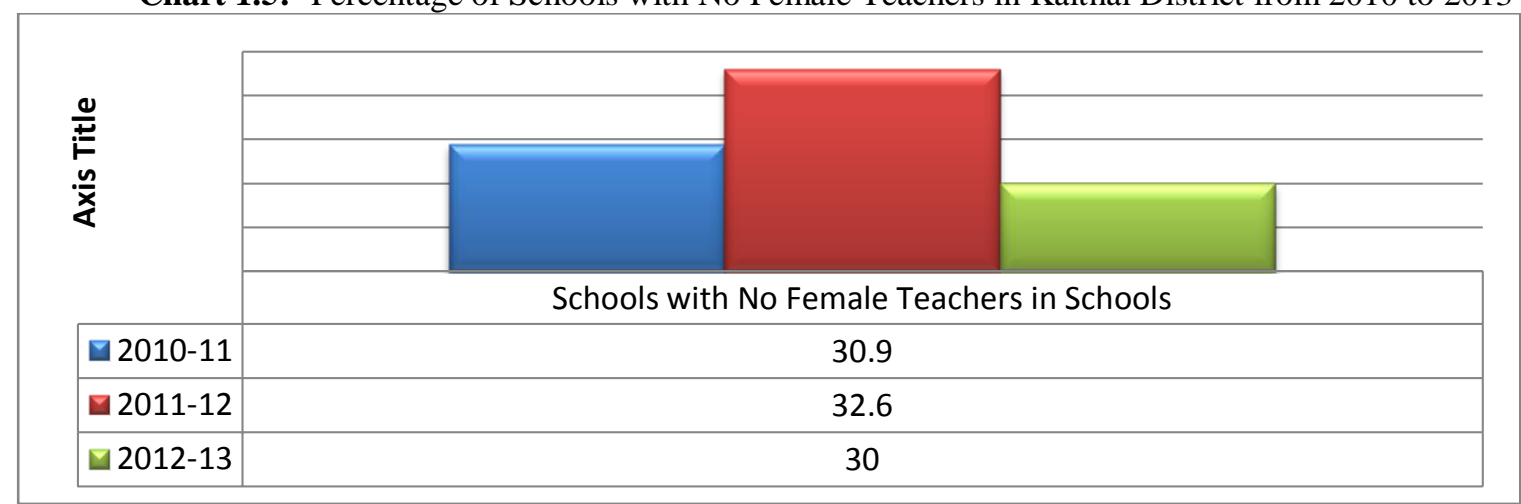

Source: DISE Report District: Kaithal, Year 2010-11; 2011-12 and 2012-13 Elementary Education in India- Where do we stand? District: Kaithal

\section{School with at least one Female Teacher in Schools in Kaithal District:-}

Studies shows that female teachers are inheritably more sensitive towards children, so it is apparent that there must atleast one female teacher in school. Chart 1.6 indicates that there is decrease in the percentage of schools with at 
least one female teacher in school. In 2010-11, 39.1\% schools having at least one female teacher; this number increased to $38.5 \%$ in $2012-13$.

Chart 1.6:- School with Female Teachers in Schools in Kaithal District from 2010 to 2013

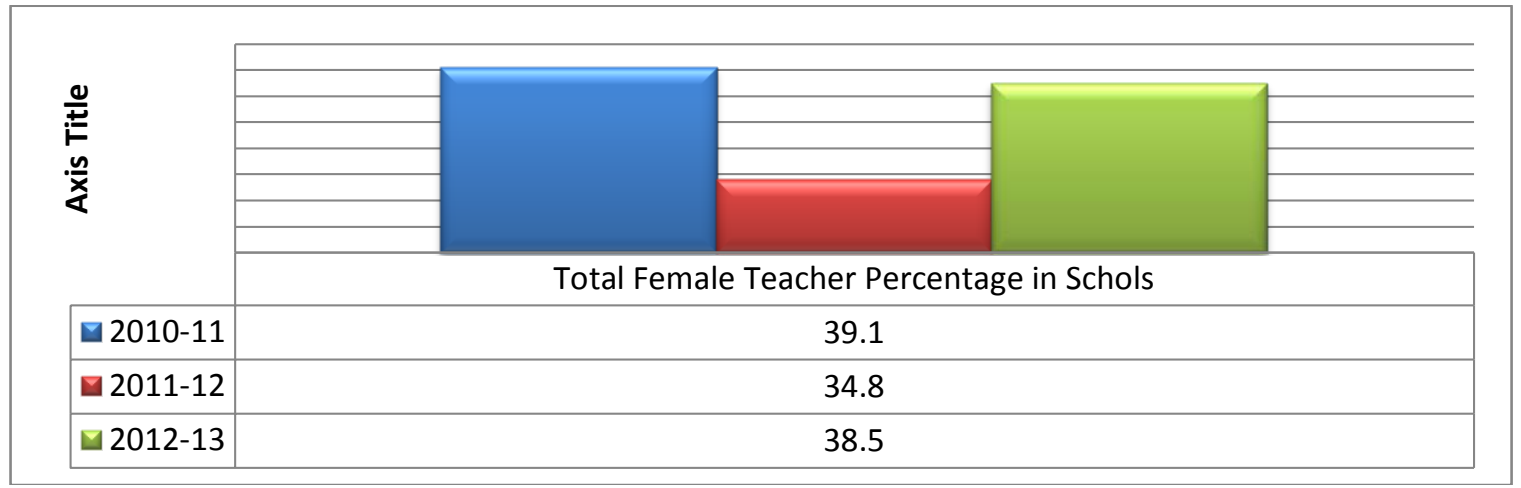

Source: DISE Report District: Kaithal, Year 2010-11; 2011-12 and 2012-13 Elementary Education in India- Where do we stand? District: Kaithal

\section{Teachers Related Indicators in Kaithal District:-}

Fig. 1 shows the standardized norm regarding Classroom Teacher Ratio and Pupil Teacher Ratio in schools under Right to Education Act 2010.

Fig 1:- Teacher Pupil Ratio and Classroom Ratio.

\begin{tabular}{l} 
Teacher Pupil Norms Under Right to Education Act, \\
- Mupil Teacher Ratio \\
- 61 to 90 Pupil = 3 Teachers \\
- 91 to 120 Pupil = 4 Teachers \\
- 121 to 200 Pupil = 5 Teachers \\
- More then 150 Pupil = 5 + 1 Head Teacher \\
- More then $200=$ Pupil Teacher Ratio Shall not exceed 40Pupil \\
\hline From 6th to 8th Class \\
- At Least 1 Teacher for every 35 Pupil
\end{tabular}

Teacher Pupil Ratio (TPR) and Student Classroom Ratio (SCR) are important performance indicators for primary education. Chart 1.7 indicates that there is growth in TPR and SPR in Kaithal District in Haryana from 2010 to 2013.

Increase in the number of teachers is reflected in the pupil-teacher ratio and student classroom ratio which has shown consistent improvement. Overall PTR was hovering around 38 in 2010-11; it has reduced paramount to 31 in 2012-13.

Student teacher ratio also improved significantly from 33 to 28 within 3 years from 2010 to 2013. 
Chart 1.7:- Percentage Performance Indicators in Schools viz Pupil Teacher Ratio and Student Class Room Ratio in Kaithal District 2010 to 2013

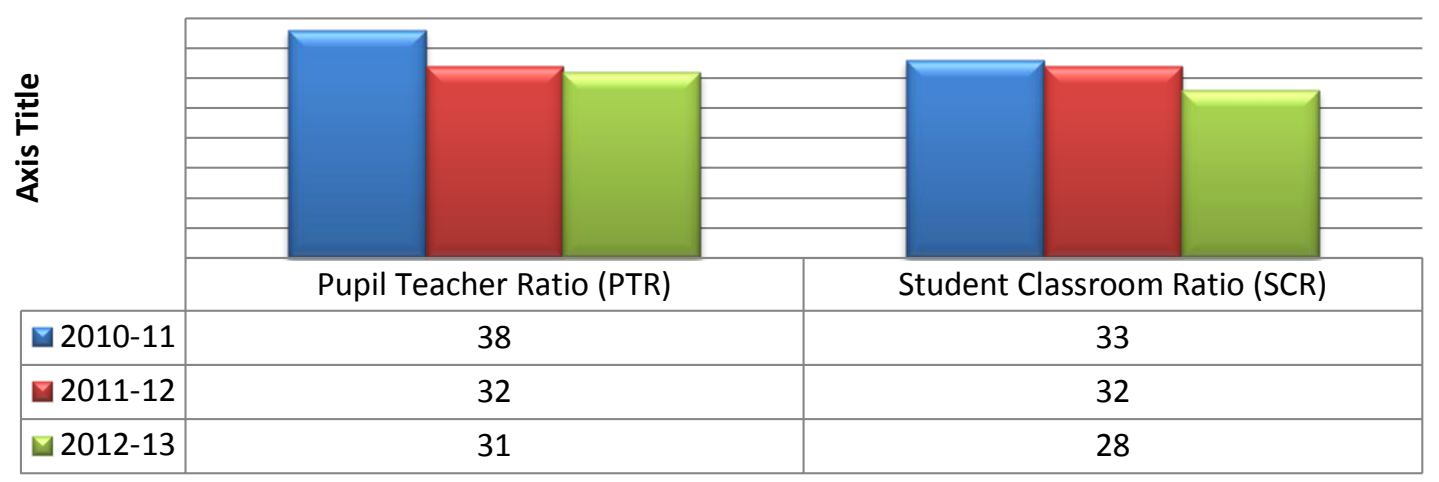

Source: DISE Report District: Kaithal, Year 2010-11; 2011-12 and 2012-13 Elementary Education in India- Where do we stand? District: Kaithal

Educational Qualification of Teachers:-

Studies show that satisfaction higher the education qualification of teachers higher they have satisfaction, which impact on their quality teaching. As the chart 1.8 indicates that there has been increase in qualifications of teachers. It also reveals that teachers with graduate qualified are more in number as compare to other qualified teachers in Kaithal district. More qualified teachers increased from 2010 to 2013 in Kaithal district as may be pursued in chart 1.8 .

Chart 1.8:- Position of Teachers by Educational Qualification (Other than Contractual- Teachers) in Kaithal District from 2010 to 2013

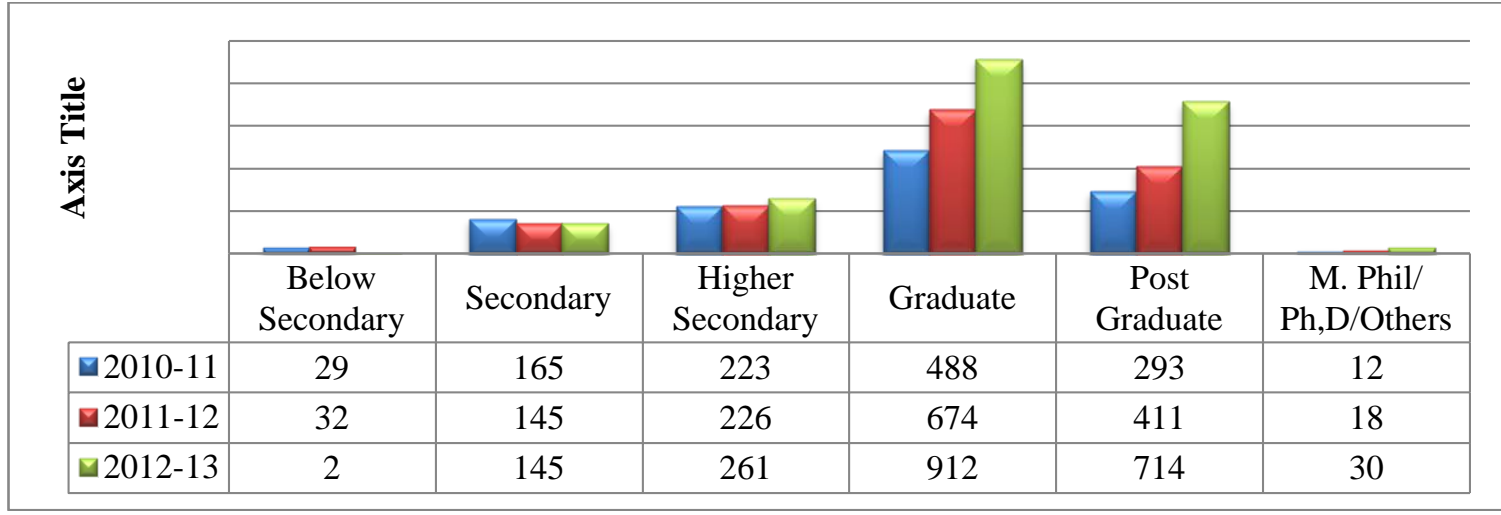

Source: DISE Report District: Kaithal, Year 2010-11; 2011-12 and 2012-13 Elementary Education in India- Where do we stand? District: Kaithal

\section{Professionally Trained Teachers:-}

Competent teachers with adequate level of knowledge, pedagogical competence, and ethical integrity are important pre-requisite for quality education. With an emphasis on professionally trained teachers in school can make a big difference in the quality education.

Chart 1.9 indicates that there are professionally trained regular teachers are more in percentage as compare to professionally trained contractual teachers in 2010-11. The Chart 1.9 also reveals that professionally trained contractual teachers decreased substantially from 2010 to 2013. 
Chart 1.9:- Percentage of Professionally Trained (Contractual and Regular) Teachers in Kaithal District 2010 to 2013

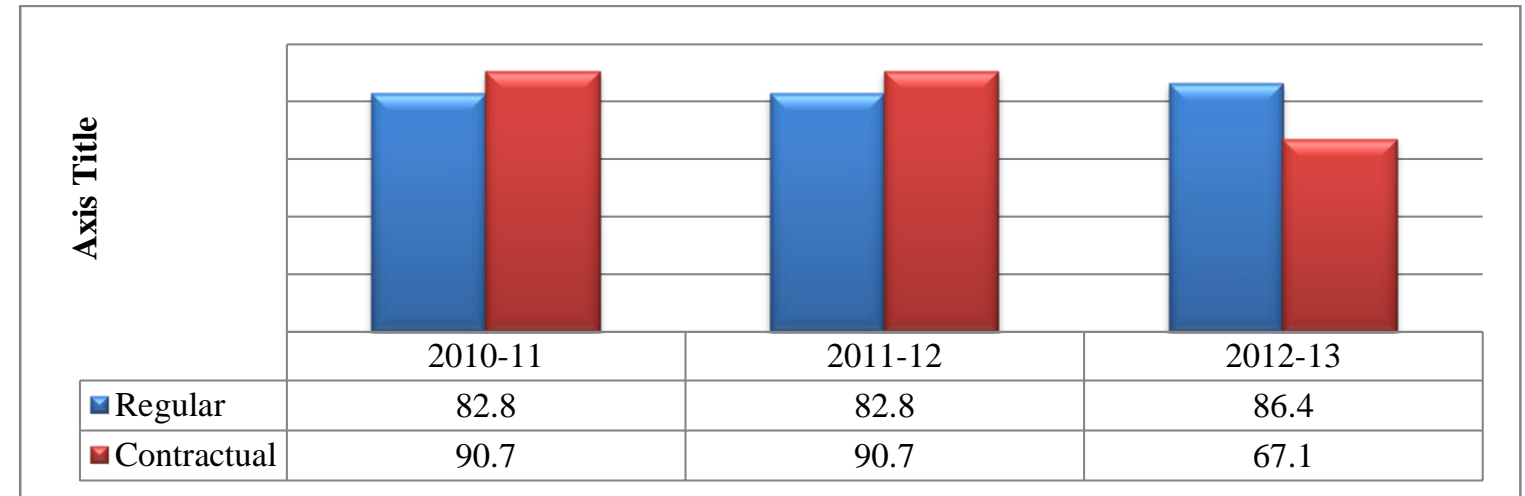

Source: DISE Report District: Kaithal, Year 2010-11; 2011-12 and 2012-13 Elementary Education in India- Where do we stand? District: Kaithal

The above statistics place the Kaithal district of Haryana, relatively at a better position, yet problems of contractual teachers, policy lags puts a question mark on the policies related to teachers. The some of the problems of primary teachers in district are discussed briefly as follows:

1. Problems of contractual teachers: There are also problems of contractual teachers who are considered as 'surplus'. Presently they are on strike as they are on roads after several years of their services.

2. Poor Deployment of Teachers: There is lag in policies related to recruitments of teachers. This result into the condition that highly qualified teachers are getting lesser services then the lesser qualified teachers.

3. Lack of Professional Qualifications: Teachers are not professionally qualified, still $13.6 \%$ regular teachers, and $32.9 \%$ contractual teachers are not professionally qualified.

4. Untrained or Semi Trained Teachers: There are several new institutional structures such as the DIET,BRC and $\mathrm{CRC}$ have been created to meet the capacity building needs of teachers in more comprehensive manner. However, to district and block levels has brought to light the fragility of expertise available at these levels.

5. Problems related to teachers continue to be a major challenge for educational planners and administrators. These challenges cannot be met without undertaking the needs of teachers.

\section{Conclusion and Suggestions:-}

Administrative gaps, financial hurdles, quality less education, and other many policy or program lags can be easily taken over by improved governance. Strong political will and administrative accountability can do wonders in upliftment and achievement of desired level of education and better recruitment related policies for teachers. It may be the scarcity of finances or poor deployment of teacher, teacher training. There is a need to increase, transparency, accountability, responsiveness in the education system. Targeted investment of adequate resources with disaggregated actions are necessary to reduce regional and inter-state disparities and simultaneously focusing on awareness generation among people a results-based approach to education in order to pursue primary education goals of "learning for all" in a post-2015. 